\title{
Competition for resources between neighbouring species and patch scale vegetation dynamics in temperate grasslands
}

\author{
Jean-François Soussana*, Michel Lafarge
}

Inra, unité d'agronomic, 234, avenue du Brézet, 63039 Clermont-Ferrand cedex 02, France

(Received 28 May 1998; accepted 25 September 1998)

\begin{abstract}
Using experimental results obtained mainly with monocultures and mixtures of grasses and of legumes, we argue for the need of a mechanistic and quantitative understanding of resource partitioning among grassland species. An individual-based approach of species compctition at the patch scale is discussed and we show that the coexistence of grassland species is favoured by morphological and physiological adjustments to the resource levels and to the neighbour densities they encounter. It is argued that such adjustments tend to increase the stability and the resilience of grassland communities and that the inclusion of such phenomena in models may improve our understanding of the vegetation dynamics and our ability to control it. An individual-based model that simulates an homogeneous patch consisting of two species (grasses or legumes) is presented and it is shown that such a model may help to understand some of the major traits (functional types) that favour the dominance of species in communities. Finally, the need for spatially explicit models of plant competition taking into account the clonal growth of pasture species is stressed. () Elsevier/Inra
\end{abstract}

\section{competition / diversity / coexistence / morphogenesis / $\mathrm{C}$ balance / $\mathrm{N}$ uptake / $\mathrm{N}_{2}$ fixation}

Résumé - Compétition interspécifique pour des ressources et dynamique locale de végétation dans les prairies tempérées. À partir de résultats expérimentaux obtenus avec des cultures pures ou associées de graminées et de légumineuses prairiales, la nécessité de disposer d'estimations quantitatives du partage des ressources entre espèces est discutée. Une approche écophysiologique de la compétition est proposée et nous montrons que la coexistence des espèces prairiales est favorisée par des ajustements morphologiques et physiologiques au niveau des ressources, ainsi qu'à la densité des voisins. Nous estimons que de tels ajustements permettent d'accroître la stabilité et la résilience des communautés prairiales et que l'inclusion de ces mécanismes dans des modèles peut améliorer notre compréhension de la dynamique de végétation, ainsi que notre aptitude à la contrôler. Un modèle simulant la croissance de deux espèces (graminées ou légumineuses) dans une zone homogène est présenté et nous montrons que ce modèle permet de déterminer certains des

\footnotetext{
* Correspondence and reprints
}

Tel.: (33) 04736244 23; fax: (33) 04736244 57; e-mail: soussana@clermont.inra.fr 
traits (types fonctionnels) qui favorisent la dominance des espèces dans un mélange. Enfin, la nécessité de disposer de modèles spatialement explicites de la compétition, prenant en compte la croisance clonale des espèces prairiales, est soulignée. (1) Elsevier/Inra

compétition / diversité / coexistence / morphogenèse / bilan de carbone / absorption d'azote / fixation biologique d'azote

\section{INTRODUCTION}

Semi-natural grasslands in Europe are managed to meet a number of objectives, including the productivity and quality of the herbage, conservation of biodiversity and the maintenance of landscapes. Such goals are usually attained through various management practices (e.g., grazing, cutting and fertiliser inputs) which affect both the growth and the botanical composition of swards.

Apart from their direct impacts on the vegetation (through defoliation, treading and excreta), most management practices have also large indirect effects, through changes in the above and below-ground environments, which alter the growth of the herbage and the competitive interactions between individual plants. Few competition studies have clearly and unequivocally concluded that competition is the major selective force in pasture communities. However, it is clear that competition is at least of some importance and that it does contribute to community structure within the constraints set by environmental conditions, nutrients cycling and grazing [59].

Plant competition has been defined as: 'an interaction between individuals, brought about by a shared environment for a resource in limited supply, and leading to a reduction in the survivorship, growth and/or reproduction of the competing individuals' [3]. From this contemporary definition, it appears that the study of competition needs to consider both population biology and ecophysiology (resource capture and use). In this review, we discuss how a wide range of physiological and morphological mechanisms of resource uptake and utilisation can be related to the performance of individuals and populations as mediated by competition.

\section{A POPULATION BIOLOGY APPROACH TO SPECIES COEXISTENCE}

Understanding the coexistence of species has been and remains a central objective in ecology. The principle of competitive exclusion was established early this century and was first formulated mathematically by Lotka [34] and, independently, by Volterra [61]. Using a simple model for the density dependence of mixed population growth, they demonstrated that the coexistence of species in mixtures occurs when the effects of either species on itself exceeds the effect it has on the other species. In this case, interspecific competition is relatively small and a stable coexistence is possible. Another prediction of the Lotka-Volterra model is that when there is strong competition between species the outcome depends on the initial conditions. Hence, there are four equilibrium outcomes of two-species competition in the Lotka-Volterra equations: competitive exclusion of species $A$ by species $B$, competitive exclusion of species $B$ by species $A$, stable coexistence, and founder control (the equilibrium outcome of competition is unstable and depends on initial conditions). A founder control has the effect of making the outcome of a competition highly dependent upon the initial advantage. This may account for the rela- 
tive indeterminacy of relative abundance of species in many grassland communities.

A large number of experiments attempted to test the Lotka-Volterra equations experimentally, using either replacement or addition designs. A mixture of two species or forms is the simplest model of diversity for experimental studies. In additive designs two species are grown together, the density of one is maintained constant and that of the other is varied. Such an experimental design has an obvious relevance to many field situations in which one species is invading the area occupied by another and it allows to test the role per se of the addition of a competitor [27]. By contrast, de Wit's [64] replacement series involve sowing two species in varying proportion while maintaining overall density constant. In this case, part of the competition within a species ('intra-specific') is replaced by inter-specific competition.

When two species of grass are grown together in mixtures, the yield does seldom exceed that of the higher yielding pure stand
[16]. By contrast, grass-legume mixtures frequently outyield the pure stands $[20,29$, 48]. In most replacement experiments, mixing a grass with a legume improves the nitrogen nutrition of the grass [11]. This does not necessarily imply a transfer of biologically fixed $\mathrm{N}$ from the legume to the grass, as soil $\mathrm{N}$ is in relative terms more available to the grass plants in a mixture, due to the reduction of the grass density and to the lower competitive ability for $\mathrm{N}$ uptake of the legume $[10,47]$. The yield gain obtained by sowing perennial ryegrass in mixture with white clover is closely related (figure l) to the improvement in the nitrogen status of the mixed, compared to the pure, grass sward. This yield gain is greater at low than at high fertiliser $\mathrm{N}$ supply [48], which shows, as with a number of studies in the literature (reviewed by Harper [27]), that the competitive interactions between a grass and a legume are strongly affected by the availability of inorganic $\mathrm{N}$.

From this example, it can be seen that the coefficients of interaction between

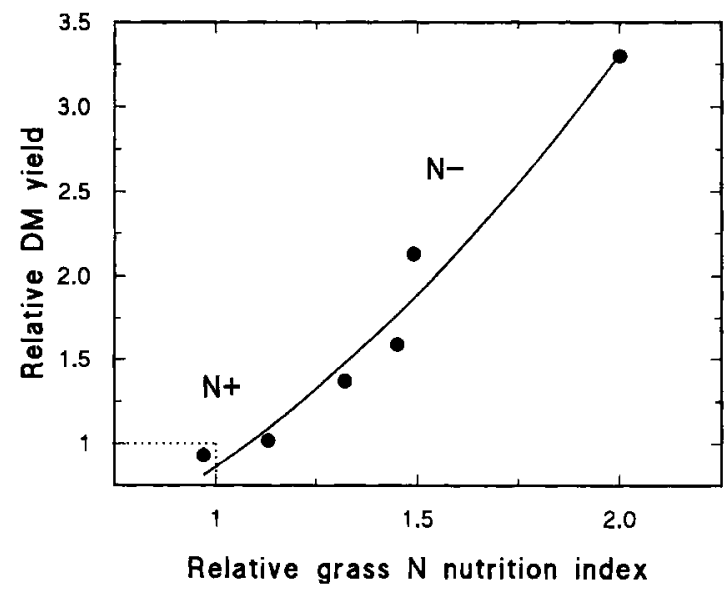

Figure 1. Relative dry-matter yield of a grass-clover mixture as a function of the relative nitrogen nutrition index of the grass (data from Soussana and Arregui [48]). The relative yield and the relative $\mathrm{N}$ nutrition index were calculated by dividing the value for the mixture by the corresponding value for the pure grass stand. The nitrogen nutrition index of the pure and mixed grass was calculated according to Soussana and Arregui [48] as the measured leaf $\mathrm{N}$ concentration divided by the optimal leaf $\mathrm{N}$ concentration. Different $\mathrm{N}$-fertiliser supplies (in the range $0-200 \mathrm{~kg} \mathrm{~N} \cdot \mathrm{ha}^{-1}$ ) were compared $\left(\mathrm{N}^{-}\right.$and $\left.\mathrm{N}^{+}\right)$during spring growth. 
species, which are fixed in the LotkaVolterra equations, are in fact a function of the environment and of the availability of resources. Therefore, density-based models, like the Lotka-Volterra equations, can predict the dynamics of species interactions only in the environment in which their parameters were calibrated.

\section{A RESOURCE BASED THEORY OF COMPETITION}

Few grassland habitats have been found to have more than a handful of limiting resources, even though the habitat may contain several hundred species [26]. How can multiple plant species coexist on a few resources only?

Tilman [56] developed a resource based theory of competition. The model consists of a pair of consumer-resource equations describing resource dependent plant population growth and resource dynamics. According to this model, the critical resource concentration $\mathrm{R}^{*}$ is a key parameter for competitive success. It can be measured in the field as the concentration to which a limiting resource is reduced by a steady-state monoculture. $\mathrm{R}^{*}$ will vary with the relative requirements for nutrients, which are increased by nutrient losses (through the abcission of leaves, the turnover of roots, or herbivory) [4]. If all species are limited by the same nutrient, the species with the lowest $R^{*}$ is predicted, at equilibrium to displace all competitors, independent of their initial densities [56]. An environmental heterogeneity in the ratios of two or more limiting resources could still permit a significant number of species to co-occur in a small area. However, this explanation requires a separate limiting resource for each species and it is only spatial heterogeneity that accounts for the observed diversity of grassland community [23].

Tilman's resource competition theory is capable of predicting the long-term outcome of interspecific competition at equilibrium in natural relatively undisturbed habitats [57]. By contrast, in managed permanent grasslands, competition interacts continuously with the disturbance induced by grazing or mowing, which arrests the pasture from developing into shrub and forest [59]. The non-equilibrium dynamics of species competition for resources, is therefore of major importance for the structure of grazed grasslands. In order to understand this dynamic, the main physiological mechanisms of resource uptake and use by competing grassland species should first be analysed.

\section{COMPETITION FOR LIGHT}

Competition for light, which is conspicuous in fertile grasslands, is usually considered as asymmetric: larger individuals obtain a disproportionate share of the light resource and suppress the growth of smaller individuals [42]. Competition for light is thus considered to be the primary cause of size asymmetry and self-thinning in dense populations [27] and it is often assumed that when light competition predominates, there is little opportunity for species coexistence, resulting in a strong decline in diversity [30].

The degree of size asymmetry caused by competition for light can be investigated by modelling light partitioning between species grown in mixture. A model of radiation interception [45] was applied to grass-clover mixtures by Faurie et al. [19]. Simulations showed that the advantage of clover in terms of photosynthetically active radiation (PAR) capture was suppressed by nitrogen-fertiliser supply because of a lack of vertical dominance of the legume at high $N$ [19]. The equation by Schwinning and Fox [40] can be applied to these results, in order to calculate the size symmetry or asymmetry of competition for light. With this equation, the division of incident radiation (PAR) between $n$ species can be calculated according to their average size (leaf area per plant, 
LA). PAR ${ }_{i}$ refers to the average amount of PAR absorbed by plants from species $i$ of leaf area $L A_{i}$. The parameter $\theta$ indicates the mode of competition from symmetric $(\theta \leq 1)$ to asymmetric $(\theta>1)$ :

$$
P A R_{i}=\operatorname{PAR} \cdot\left(L A_{i}{ }^{\theta} / \sum_{j=1}^{n} L A_{j}{ }^{\theta}\right)
$$

When clover was dominant, the value of $\theta$ was greater than one $(1.5 \pm 0.2)$, which indicates that light capture increased more than proportionally with leaf area (size asymmetry). By contrast, with a dominant grass, competition for light was size symmetric as $\theta$ was lower than one $(0.7 \pm 0.1)$. In this case, the light capture still increased with the average leaf area per plant but less than proportionally. According to the current theory [42], the symmetry/asymmetry of competition for light is expected to affect species balance. Nevertheless, even when competition for light was partly asymmetric (dominant clover), the balance between species which was established in the grassclover mixture at the time of canopy closure was not modified thereafter [13, 19].

This result can be better understood by considering how declines in light quality and quantity trigger shade avoidance in a pasture species like white clover. Clover reacts quickly to shading by increasing its petiole length $[52,60]$. As the ratio of the extended length of clover petioles and grass leaves is approximately constant [14], the effects of competition for light for clover are buffered. This morphological response to shading has, however, major costs for the legume like the suppression of branching [44] and a mortality of small apices [49], which was shown to be caused by leaf light intensities below compensation point [22].

Shade tolerance may also contribute to stabilise the botanical composition of crowded stands. Leaves that are photosynthetically light saturated have a lower radiation use efficiency. By contrast to a monoculture, the fraction of leaf in the shade can reach one for a shaded species within mix- ture. In this case, due to the avoidance of light saturated photosynthesis, the radiation use efficiency tends to increase $[19,62]$. As shading increases the radiation use efficiency of subordinate species, these will use light more efficiently and by acquiring shade plant characteristics, they may be able to delay competitive exclusion until light becomes again available because of defoliation by grazing or cutting. Hence, physiological (shade tolerance) and morphological (shade avoidance) responses to shading tend to increase the possibilities for species coexistence in fertile grasslands.

\section{BELOW-GROUND COMPETITION FOR NUTRIENTS}

The available data suggest that belowground competition for nutrients is usually size-symmetric [42], which appears to be consistent with the basic mechanisms of soil resource interception, as two proximate roots will both generate depletion zones around their surfaces and thus restrict the resource supply of the other [2]. In case of little mobile ions like phosphate, many local depletion zones will develop that have little overlap with the zones of adjacent plants. This may allow a plant to be limited by a below-ground nutrient without necessarily having a strong impact on the resources available to another plant [30]. According to the model by Huston and DeAngelis [30], under low to medium fertility as competition is predominantly below-ground, a substantial number of plant species can coexist.

Although fast-growing species are able to grow faster even at low nutrient levels, inherently slow-growing species appear to have an advantage in nutrient poor sites [7, 33]. Efficient nutrient conservation due to long life span of the organs has often been suggested as an explanation for the longterm success of slow-growing species $[4,7$, 24]. According to the model by Aerts and van der Peijl [1], the species with higher nutrient productivity (dry weight produced 
per unit nitrogen taken up) grow initially faster at low nutrient supply, but in the long term the species with higher mean residence time for nutrients attain the higher biomass. With three ecologically contrasting grass species, high relative growth rates were correlated with short lifespans of the roots and shoots and with low tissue density [43]. Low tissue density has also been found to be an important component of the high leaf area ratio and high root length ratio of grass species [21, 39].

Nitrogen uptake by grassland species can be modified both by competing neighbour plants and by defoliation. In mixtures of Lolium perenne with Festuca rubra, the ability to compete for nitrate uptake was reduced for each species by increasing its cutting frequency [55]. After cutting, storage pools are used in pasture plants both to support regrowth and to buffer the internal nutrient status [54]. With slow-growing species of infertile soils such as Festuca ovina, large reserve pools tend to uncouple growth from nutrients uptake and such species are also more able to capture nitrogen from short pulses than fast-growing species [25]. Slowgrowing species which are tolerant to nutrient stress display thus a range of adaptations (low tissue turnover, ability to use nutrients pulses) that tend to lower their nutrients requirements and, hence, to reduce their critical nutrient concentration, stricto sensu Tilman [56].

Some other adaptations are involved in the avoidance of nutrient stress by fast-growing grassland species. Supply of nutrients from the soil is usually assumed to be from a combination of mass flow and diffusion. With a highly mobile nutrient like nitrate, mechanistic models of uptake have shown that the main parameters controlling the flux are the root uptake capacity, the root surface area and the total amount of nutrient in the soil [2]. The first two of these parameters are controlled by the plant and, with fast-growing species like perennial ryegrass, adaptive responses to $\mathrm{N}$ deprivation involve increases both in the root:shoot ratio and in the root uptake capacity [46]. Morphological (increase in root mass and in root length) and physiological (de-represssion of uptake, [31]) adjustments to nutrients deprivation caused by neighbours may therefore avoid or at least delay the competitive suppression of fast-growing grasses.

Other fast growing pasture species are legumes which avoid $\mathrm{N}$ deprivation by supplementing inorganic $\mathrm{N}$ uptake with symbiotic $\mathrm{N}_{2}$ fixation, thereby retaining a relatively high growth rate even in a low $\mathrm{N}$ soil environment. Nitrogenase activity in forage legumes is apparently fine tuned to the growth rate and, hence, to the nitrogen demand of the plant, mainly through changes in the nodule mass and in the oxygen permeability of the nodules $[17,28]$. In contrast to a grass, the nitrate uptake capacity of a legume like white clover is little repressed by a high internal $\mathrm{N}$ status [46]. Because of this lack of repression of nitrate uptake, clover is able to compete efficiently with a grass at high $\mathrm{N}$ availability. This may limit the dominance of the grass in a high soil $\mathrm{N}$ environment and its ability to shade and suppress the legume [18].

Hence, when neighbouring species are competing for soil nutrients like inorganic $\mathrm{N}$ a number of physiological and morphological adaptations seem to delay competitive exclusion. Slow-growing species tend to be tolerant to $\mathrm{N}$ deprivation, at least when they are not cut frequently, while fast-growing species tend to avoid $\mathrm{N}$ deprivation either through morphological and physiological adaptations, or by developing a symbiosis with $\mathrm{N}_{2}$ fixing Rhizobium bacteria.

\section{MODELLING THEALLOCATION OF GROWTH AND THE COMPETITION FOR MULTIPLE RESOURCES}

A mechanistic understanding of whole plant allocation is still lacking, although some conceptual progress was made [35], based upon the widely acknowledged theory 
of phloem transport by Münch [36]. Recent developments in molecular biology have shown that some sugars act as signals for the expression of various genes involved both in carbohydrate production and use as well as in tissue growth [32]. Moreover, the involvement of chemical (especially through abcissic acid) and hydraulic signalling effects has been demonstrated for a number of processes, including stomatal aperture and leaf extension [15]. Given the complexity and the diversity of these regulations, it is unlikely that a fully mechanistic model of whole plant allocation can be developed in the near future. Nevertheless, the hypothesis of a functional equilibrium that would preserve a balance between photosynthesis and mineral nutrient capture through effective homeostatic mechanisms that modify the allocation between roots and shoots $[6$, 12] is supported by a large body of experimental evidence [63].

The most efficient allocation for an individual plant would in no resources being taken up in excess, so that all resources would limit growth simultaneously [8]. By contrast to the hypothesis of an optimisation of whole plant growth, this 'multiple limitation' hypothesis does not imply that the plant can 'foresee' the environmental conditions it will experience during a growth period in a fluctuating environment [38].

Using the multiple limitation hypothesis, an individual-based model ('Canopt', [51]) of competition between grassland species was constructed. The allocation submodel specifies a target root:shoot ratio, according to the functional equilibrium hypothesis and a target leaf protein content, that ensures a co-limitation of leaf photosynthesis by the Rubisco activity and by the electron flux [50]. The model describes explicitly the leaf and canopy architecture and simulates mechanistically the competition for light and the competition for inorganic $\mathrm{N}$ between species [51].

With this model, the outcome of competition for two major resources (light and $\mathrm{N}$ ) can be simulated quantitatively at different cutting frequencies (figure 2). The non-equilibrium dynamics of species competition can thus be investigated, in interaction with the disturbance induced by mowing (or grazing). Simulations were run, considering two identical grass populations grown in mixture during 1 year under optimal conditions $\left(\mathrm{N}^{+}\right)$and in a low $\mathrm{N}$ soil environment $\left(\mathrm{N}^{-}\right)$ and cut 3 to 36 times per year (regrowth length comprised between 10 and $120 \mathrm{~d}$ ).

In figure $2 A$, in order to study the effects of size asymmetry, the initial mass of population 1 was halved. Under $\mathrm{N}$ deprivation $\left(\mathrm{N}^{-}\right)$, the initial asymmetry in the individual size of the grass tillers did not affect the outcome of competition and, after 1 year simulation, each population accounted for approximately one half of the total mass of the mixture at all cutting frequencies. In the same way, the initial size asymmetry did not affect the species balance for short regrowth duration at $\mathrm{N}^{+}$. By contrast, for long regrowth duration at a non limiting $\mathrm{N}$ supply $\left(\mathrm{N}^{+}\right)$, the initial size asymmetry led to a low abundance of population 1 after 1 year simulation. These simulation results show, in agreement with the literature [42], that size asymmetry may lead to competitive exclusion under severe competition for light (infrequent cuts with a fertile soil), but that this is not likely to occur in a $\mathrm{N}$ poor environment, where competition occurs mostly below-ground, and at high disturbance rates (high cutting frequency).

In figure $2 B$, the two grass populations were assumed to have the same initial size, but the lifespan of leaves and of roots was doubled in population 1 compared to population 2. After 1 year simulation, for long regrowth durations, the results indicate a strong dominance of species 1 both for a low and for a high availability of soil N. By contrast, in a frequent cutting regime (less than $30 \mathrm{~d}$ of regrowth), the population with the greatest leaf and root turnover (i.e., population 2) became dominant. Hence, these results support the concept put forward by 


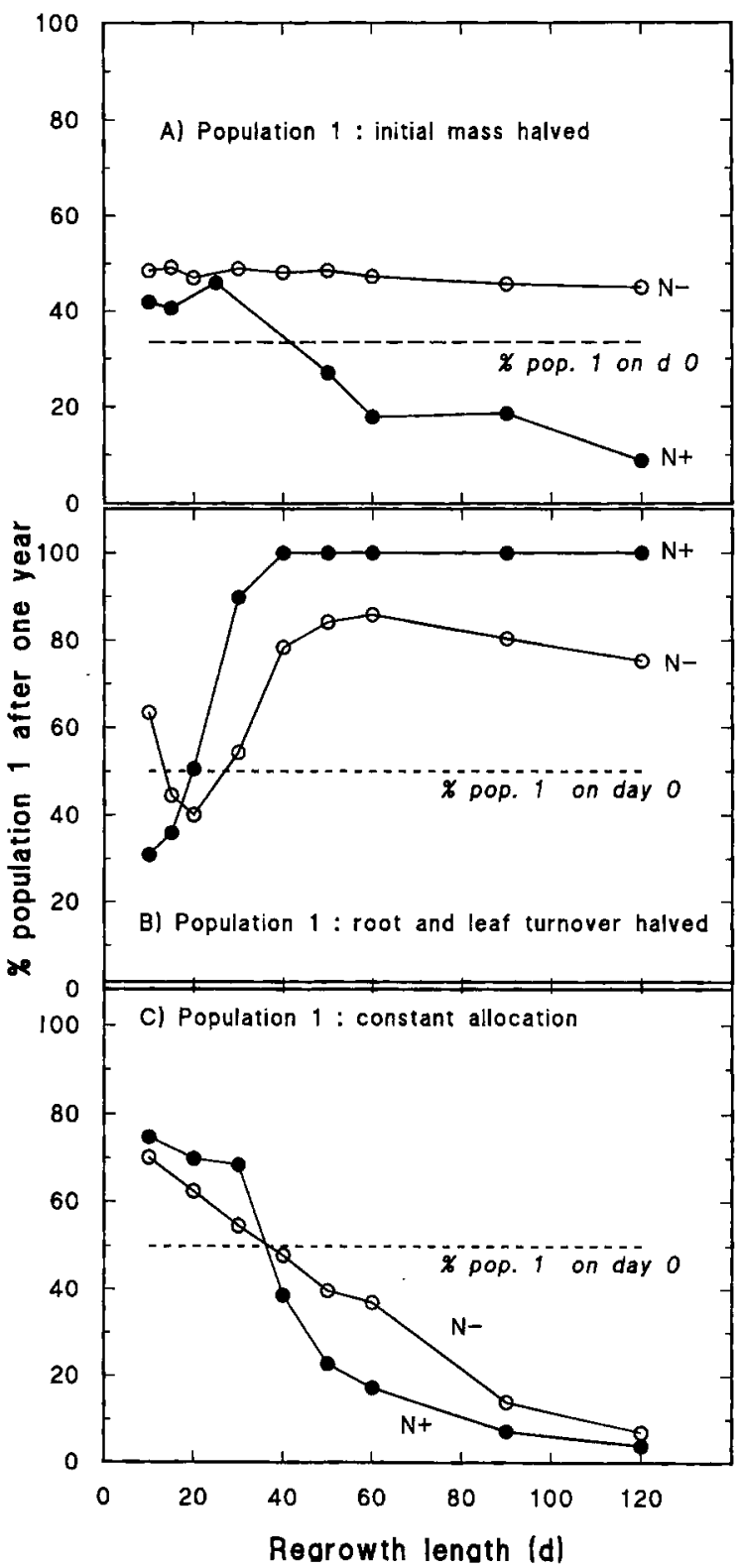

Figure 2. Simulation with Canopt of mixtures consisting of two identical grass populations, differing only: in the initial mass per tiller, which was halved for population $\mathbf{I}(\mathbf{A})$; in the root and leaf turnover rates which were halved for population I (B); in the allocation pattern $(\mathbf{C})$; a fixed allocation pattern was considered for population 1 , resulting in the same allocation rate per unit mass for the roots, shoot structures and leaf proteins. Simulations were run during $360 \mathrm{~d}$ at $18{ }^{\circ} \mathrm{C}$ under $500 \mu \mathrm{mol}$ PAR $\mathrm{m}^{-2} \mathrm{~s}^{-1}$ with a photoperiod of $14 \mathrm{~h}$ under optimal soil $\mathrm{N}$ conditions $\left(\mathrm{N}^{+}\right)$and in a low $\mathrm{N}$ soil environment $\left(\mathrm{N}^{-}\right)$. The simulated swards were cut at $4 \mathrm{~cm}$ height 3 to 36 times per year, resulting in a regrowth length comprised between 10 and $120 \mathrm{~d}$. 
Chapman and Lemaire [9] that leaf (and root) turnover are of major importance for the vegetation dynamics in a disturbed (grazed) grassland. Long leaf and root life spans would be beneficial for low cutting frequencies, both because they allow a greater size of the leaves and because they lower the nutrient losses created by the senescence and abcission of the plant tissues. By contrast, in frequently grazed swards, a faster leaf turnover would be beneficial as it results in shorter leaves that may escape defoliation and in a greater number of axillary buds that may develop into new tillers. However, in a low nutrients environment, the $S$ shape of the simulation indicates that this benefit may be outweighed by the greater nutrients requirement that results from the faster turnover of the roots and leaves.

Finally, the role of the allocation plasticity (between roots, shoot structures and shoot proteins) and of a photo-morphogenetic control of leaf extension based on the relative PAR transmission [51] for the outcome of species competition was investigated (figure $2 C$ ). At low cutting frequencies, population 1 , with a fixed proportion of shoot structures, shoot proteins and roots, was less competitive than population 2. By contrast, when the duration of regrowth was below $30 \mathrm{~d}$, approximately, a fixed allocation pattern led to the dominance of the grass population 1 for the two soil $\mathrm{N}$ environments. Therefore, it seems that allocation plasticity is beneficial for long regrowth durations, but not necessarily in a frequently cut sward, as grasses with a fixed allocation pattern produce shorter leaves after cutting that partly escape defoliation. The Canopt model fails, however, to describe the changes in tiller and leaf angles that allow the avoidance of defoliation in frequently grazed grass species [5] and this renders the comparison between a fixed and a variable allocation pattern more difficult for short defoliation intervals. These simulation results show that detailed mechanistic models at the patch scale may help under- stand the patch scale vegetation dynamics. However, there are obviously several limits to this approach.

First, the disturbance created by grazing interacts continuously with neighbourhood competition in pasture species and a better understanding of the morphological and physiological responses to defoliation will be required, in order to model the grazing avoidance and grazing tolerance strategies that were reported for several pasture species [5].

Second, competition for resources occurs in a spatially structured habitat and in a variable environment. On the one hand, the adaptive value of phenotypic plasticity is likely to be reduced in a variable environment, as the traits required to maximise fitness are always changing [37]. On the other, in a spatially structured grassland habitat, significant trade-offs between the competitive ability and the ability to colonize or to disperse through seeds may favour the coexistence of grassland species [56]. Hence, there is a need to develop spatially explicit models including both neighbourhood competition and dispersal in order to understand the vegetation dynamics at the plot scale. Such models should take into account the ability of some pasture species to colonise gaps, while others tend to form large tussocks consisting of highly aggregated ramifications.

Third, there are also significant feedbacks in grasslands, between the vegetation and the soil, on the one hand, and between the vegetation and the grazing animals, on the other. Grassland ecosystem simulation models $[41,53]$ are therefore required to account for the dynamics of the grazed vegetation in the long-term and at scales greater than the patch.

\section{CONCLUSION}

Although most hypotheses that have been offered to explain the coexistence of large numbers of plant species have emphasised 
niche partitioning or disequilibrium processes, we believe that the co-occurrence of grassland species at the patch scale is also due to morphogenetical and physiological stabilising processes that are modulated by the spatial structure of the mixed plant populations. Further work will be needed to understand the functional traits that favour the coexistence of species or genotypes and their resilience to disturbance (e.g., grazing) and stress in grassland communities. From an applied viewpoint, the study of competition, in conjunction with that of the plant-soil and plant-herbivore interfaces can contribute to an integrated knowledge of the mechanisms underlying the vegetation dynamics and, hence, to the definition of management guidelines that will help to maintain the nutritional quality for herbivores of extensively grazed semi-natural grasslands.

\section{REFERENCES}

11] Aerts R., van der Peijl M.J., A simple model to explain the dominance of low-productive perennials in nutrient poor habitats, Oikos 66 (1993) 144-147.

[2] Barber S.A., Soil nutrient bioavailability. A mechanistic approach, 2nd edn., J. Wiley, NewYork, 1995

[3] Begon M., Harper J.L., Townsend C.R., Ecology: Individuals, populations and communities, 2nd. edn., Blackwell Scientific Pub., Oxford, UK, 1990

[4] Berendse F., Aerts R., Nitrogen-use efficiency: a biologically meaningfu] definition, Func. Ecol. 1 (1987) 293-296.

[5] Briske D.D., Plant response to defoliation: morphological considerations and allocation priorities, in: Joss P.J. et al. (Eds.), Rangelands: resource under siege, Cambridge Univ. Press, 1986, pp. 425-427.

[6] Brouwer R., Some aspects of the equilibrium between overground and underground plant parts, Instituut voor biologisch en scheikundig Onderzoek van Landbouwgewassen (Wageningen), Jaarboek, 1963, pp. 31-39.

[7] Chapin F.S., The mineral nutrition of wild plants, Annu. Rev. Ecol. Syst. 11 (1980) 233-260.

181 Chapin F.S., Integrated responses of plants to stress. A centralized system of physiological responses, BioScience 41 (1991) 29-36.
(9) Chapman D.F., Lemaire G., Morphogenetic and structural determinants of plant regrowth after defoliation, Proceedings of the XVII Int. Grassland Congress, New-Zealand and Australia, 1993 , pp. 95-104.

[10] Cruz P., Lemaire G., Analyse des relations de compétition dans une association de luzerne et de dactyle. Effets sur la nutrition azotée des deux espèces, Agronomie 6 (1986) 735-742.

(11) Cruz P., Soussana J.F., Mixed crops, in: Lemaire G. (Ed.), Diagnosis of the nitrogen status in crops, Springer-Verlag Pub., Berlin-Heidelberg, 1997. pp. 131-142.

112] Davidson R.L., Effects of root leaf temperature differentials on root/shoot ratio in some pasture grasses and clover, Ann. Bot. 33 (1969) 561-569.

[13] Davidson I.A., Robson M.J., Effect of temperature and nitrogen supply on the growth of perennial ryegrass and white clover. II Comparison of monocultures and mixed swards, Ann. Bot. 57 (1986) 709-719.

[14] Davies A., Evans E., Axillary bud development in white clover in relation to defoliation and shading treatment, Ann. Bot. 66 (1990) 349-357.

[15] Davies W.J., Zhang J.H., Root signals and the regulation of growth and development of plants in drying soil, Annu. Rev. Plant Physiol. 91 (1991) 55-76.

[16] Donald C.M., Competition among crop and pasture plants, Adv. Agron. 15 (1963) 1-118.

[17] Faurie O., Soussana J.F., Oxygen-induced recovery from short-term nitrate inhibition of $\mathrm{N}_{2}$ fixation in white clover plants from spaced and dense stands, Physiol. Plant. 89 (1993) 467-475.

1181 Fauric O., Interactions carbone-azote dans des associations prairiales graminée (Lolium perenne L.) légumineuse (Trifolium repens L.), Étude d'associations simulées en conditions contrôlées, thèse de doctorat. Université Blaise Pascal (Clermont-Ferrand II), 1994.

119] Faurie O., Soussana J.F., Sinoquet H., Radiation interception, partitioning and use in grassclover mixtures, Ann. Bot. 77 ( 1996) 35-45.

[20] Frame J., Newbould P., Agronomy of white clover, Adv. Agron. 40 (1986) 1-88.

121] Garnier E., Laurent G., Leaf anatomy, specific mass and water content in congeneric annual and perennial grass species, New Phytol. 128 (1994) 725-736.

122| Gossc G., Lemaire G., Chartier M., Balfourier F. Struclure of a lucerne population (Medicago sativa L.) and dynamics of stem competition for light during regrowth, J. Appl. Ecol. 25 (1988) 609-617.

[23] Grace J.B., A clarification of the debate between Grime and Tilman, Func1. Ecol. 5 (1991) 583-587. 
[24] Grime J.P., Evidence for the existence of three primary strategies in plants and its relevance to ecological and evolutionary theory, Am. Nat. 111 (1977) 1169-1194.

[25] Grime J.P., The role of plasticity in exploiting environmental heterogeneity, in: Caldwell M.M., Pearcy R.W., (Eds.), Exploitation of environmental heterogeneity by plants, Academic Press, San Diego, CA, 1994, pp. 1-19.

126] Grubb N., The maintenance of species richness in plant communities: the importance of the regeneration niche, Biol. Rev. 52 (1977) 107-145.

[27] Harper J.L., Population biology of plants, Academic Press, London, 1977, $892 \mathrm{p}$.

[28] Hartwig U.A., Heim I., Lüscher A., Nösberger J., The nitrogen-sink is involved in the regulation of nitrogenase activity in white clover after defoliation, Physiol. Plant. 92 (1994) 375-382.

[29] Haynes R.J., Competitive aspects of the grasslegume association, Adv. Agron. 33 (1980) 227-256.

[30] Huston M.A., de Angelis D.L., Competition and coexistence: the effects of resource transport and supply, Am. Nat. 144 (1994) 959-977.

[31] Imsande J., Touraine B., $\mathrm{N}$ demand and the regulation of nitrate uptake, Plant Physiol. 105 (1994) 3-7.

[32] Koch K., Carbohydrate modulated gene expression in plants, Annu. Rev. Plant Physiol. Mol. Biol. 47 (1996) 509-540.

[33] Lambers H., Poorter H., Inherent variation in growth rate between higher plants: a search for physiological causes and ecological consequences, Adv. Ecol. Res. 23 (1992) 187-261.

134| Lotka A.J., Elements of physical biology, Williams and Wilkins, Baltimore, 1925.

[35] Minchin P.E.H., Thorpe M.R., Farrar J.F., A simple mechanistic model of phloem transport which explains sink priority, J. Exp. Bot. 44 (1993) 947-955.

[36] Münch E.. Die Stoffhewegungen in der Pflanzen, Gustav Fischer, Jena, 1930.

[37] Padilla D.K., Adolph S.C., Plastic inducible morphologies are not always adaptive: the importance of time delays in a stochastic environment, Evol. Ecol. 10 (1996) 105-117.

1381 Reynolds J.F., Chen J., Modelling whole plant allocation in relation to carbon and nitrogen supply. Coordination versus optimization: opinion, Plant Soil 185 (1996) 65-74.

[39] Ryser P., Lambers H., Root and leaf attributes accounting for the performance of fast and slowgrowing grasses at different nutrient supply, Plant Soil 170 (1995) 25I-265.

[40] Schwinning S., Fox G.A.. Population dynamic consequences of competitive symmetry in annual plants, Oikos 72 (1995) 422-432.
[41] Schwinning S., Parsons A.J., Analysis of the coexistence mechanisms for grasses and legumes in grazing systems, J. Ecol. 84 (1996) 799-813.

[42] Schwinning S., Weiner J., Mechanisms determining the degree of size asymmetry in competition among plants, Oecologia 113 (1998) 447-455.

[43] Schläpfer B., Ryser P., Leaf and root turnover of three ecologically contrasting grass species in relation to their performance along a productivity gradient, Oikos 75 (1996) 398-406.

[44] Simon J.C., Gastal F., Lemaire G., Compétition pour la lumière et morphologie du trèfle blanc (Trifolium repens) : émission des feuilles et des ramifications, Agronomie 9 (1989) 383-389.

[45] Sinoquet H., Moulia B., Gastal F., Bonhomme R., Varlet-Grancher C., Modeling the radiative balance of the components of a binary mixed canopy: application to a white clover/tall fescue mixture, Acta Oecologica 11 (1990) 469-486,

[46] Soussana J.F., Faurie O., The regulation of $\mathrm{N}_{2}$ fixation and $\mathrm{NO}_{3}{ }^{-}$uptake in grass-clover mixtures, in: Emelrich C. et al. (Eds.), Biological Nitrogen Fixation for the $2 \mathrm{I}^{\text {si }}$ century, Kluwer Academic Publishers, Dordrecht, 1998, p. 662.

147] Soussana J.F., Arregui C., Hazard L., Assimilation du nitrate et fixation symbiotique dans les associations trèfle blane - ray-grass anglais, XVI International Grassland Congress, AFPF, Nice, 1989, pp. 147-148.

[48] Soussana J.F., Arregui M.C., Impact de l'association sur le niveau de nutrition azotée et la croissance du ray-grass anglais et du trèfle blanc, Agronomie 15 (1995) 81-96.

[49] Soussana J.F., Vertes F., Arregui M.C., The regulation of clover shoot growing points density and morphology during short-term decline in mixed swards, Eur. J. Agron. 4 (1995) 205-215.

[50] Soussana J.F., Teyssonmeyre F., Thiéry J., Un modèle dynamique d'allocation basé sur l'hypothèse d'une co-limitation de la croissance par les absorptions de lumière et d'azote minéral, in: Bonhomme R., Maillard P. (Eds.), Fonctionnement des peuplements végétaux et environnement, Inra, 1999, in press.

151] Soussana J.F., Teyssonneyre F., Thiéry J., Un modèle de croissance simulant les compétitions pour la lumière et l'azote entre deux espèces prairiales, in: Bonhomme R., Maillard P. (Eds), Fonctionnement des peuplements végétaux et environnement, Inra, 1999, in press.

[52] Thompson L., Harper J.L., The effect of grass on the quality of transmitted radiation and influence on the growth of white clover (Trifolium repens L.), Oecologia 75 ( 1988) 343-347.

1531 Thornley J.H.M., Grassland dynamics: an ecosystem simulation model, CAB international, Wallingford, UK, 1998. 
[54] Thomton B., Millard P., Duff E.I., Buckland S.T., The relative contribution of remobilization and root uptake in supplying nitrogen alier defoliation for regrowth of laminae in 4 grass species, New Phytol. 124 (1993) 689-694.

[55] Thornton B., Millard P., Nitrogen uptake by grasses: changes induced by competing neighbour plants differing in frequency of defoliation, Grass Forage Sci. 51 (1997) 242-249.

[56] Tilman D., Resources: a graphical-mechanistic approach to competition and predation, Am. Nat. 116 (1980) 362-393.

[57] Tilman D., Wedin D., Competition among grasses along a nitrogen gradient: initial conditions and mechanisms of competition, Ecol. Monographs 63 (1993) 199-229.

1581 Tilman D., Competition and biodiversity in spatially structured habitats, Ecology 75 ( 1994) $2-16$.
159] Turkington R., Mehrhoff L.A., The role of competition in structuring pasture communities, in: Tilman D., Grace J.B. (Eds.), Perspectives on plant competition, Academic Press, San Diego, 1990, pp. 307-340.

[60] Varlet-Grancher C., Moulia B., Jacques R., Phytochrome mediated effects on white clover morphogenesis, XVI international Grassland Congress, Nice I. 1989. pp. 477-478.

1611 Volterra V.. Fluctuations in the abundance of a species considered mathematically, Nature 118 (1926) 558-560.

|62| Willey R.W., Resource use in intercropping systems, Agricult. Water Management 17 (1990) $215-231$.

163] Wilson J.B., A review of evidence on the control of shoot: root ratio in relation to models. Ann. Bot. 61 (1988) 4.33-449.

[64] Wit C.T. de, On competition, Versi. Landbouwk. Onderz. 66(1960) 1-82. 